\title{
Extensive striatal, cortical, and white matter brain MRI abnormalities in Wilson disease
}

Figure White matter, cortical, and striatal abnormalities (brain MRI)
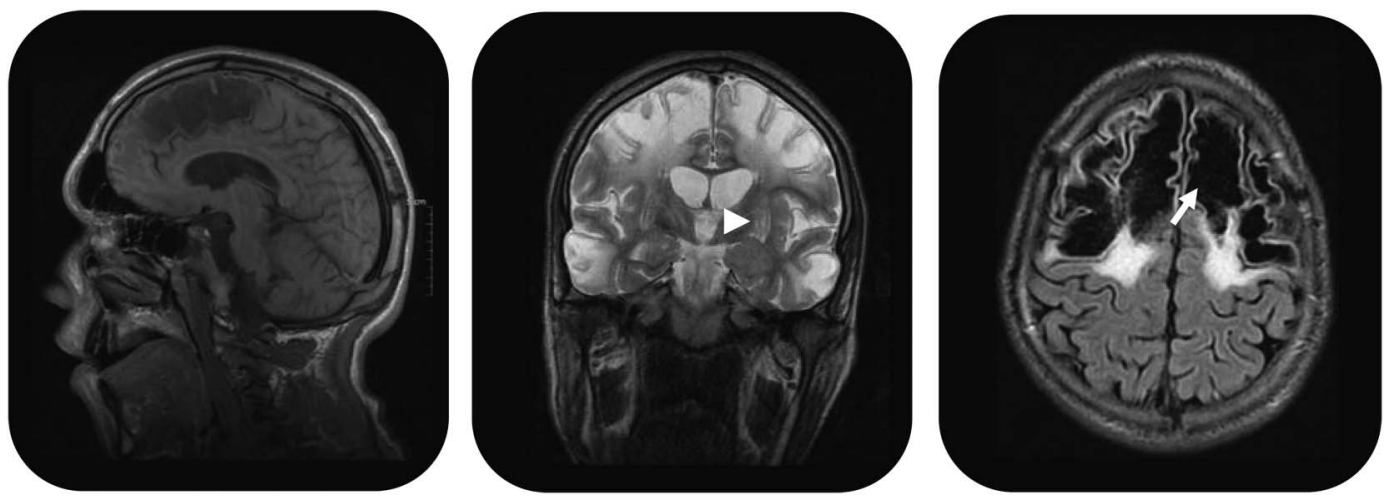

Diffuse bilateral white matter, cortical, and striatal (arrowhead) abnormalities, with cystic aspect (arrow) in frontal region (fluid-attenuated inversion recovery).

A 16-year-old boy presented with progressive dysarthria and gait and behavior disorders. The diagnosis of Wilson disease was made, based on Kayser-Fleischer rings, hypocupremia, hypoceruloplasminemia, and increased 24-hour urinary copper, and confirmed by molecular analysis (homozygous state, p. [Glu1382*]; [Glu1382*]). Brain MRI demonstrated diffuse bilateral cortical and subcortical abnormalities (figure). Chelator therapy (D-penicillamine) produced partial improvement, although the patient developed epileptic seizures, presumably due to the cortical involvement. Wilson disease with extensive cortical-subcortical lesions is rare, ${ }^{1,2}$ but should be considered as a possible etiology of diffuse leukoencephalopathy with cystic evolution.

Jean-Marc Trocello, MD, PhD, France Woimant, MD, Souleiman El Balkhi, PhD, Jean-Pierre Guichard, MD, Joel Poupon, PhD, Philippe Chappuis, PhD, Francois Feillet, MD, PhD

From the French National Reference Centre for Wilson's Disease (J.-M.T., F.W.), Biological Toxicology Laboratory (S.E.B., J.P.), Neuroradiology (J.-P.G.), and Laboratoire de Biochimie et Biologie Moléculaire (P.C.), AP-HP, Hôpital Lariboisière, Paris; and National Reference Centre for Inborn Errors of Metabolism (F.F.), INSERM U954, Nancy, France.

Author contributions: Dr. Trocello: design, conceptualization, drafting the manuscript. Dr. Woimant: design, conceptualization, drafting the manuscript. Dr. El Balkhi: interpretation of data, revising the manuscript. Dr. Guichard: interpretation of data, revising the manuscript. Dr. Poupon: interpretation of data, revising the manuscript. Dr. Chappuis: interpretation of data, revising the manuscript. Dr. Feillet: conceptualization and revising the manuscript.

Study funding: No targeted funding reported.

Disclosure: The authors report no disclosures relevant to the manuscript. Go to Neurology.org for full disclosures.

Correspondence to Dr. Trocello: jean-marc.trocello@lrb.aphp.fr

1. Mikol J, Vital C, Wasse M, et al. Extensive cortico-subcortical lesions in Wilson's disease: clinico-pathological study of two cases. Acta Neuropathol 2005;110:451-458.

2. Shimoji A, Miyakawa T, Watanabe K, Yamashita K, Katsuragi S, Kabashima K. Wilson's disease with extensive degeneration of cerebral white matter and cortex. Jpn J Psychiatry Neurol 1987;41:709-717. 


\section{Neurology}

\section{Extensive striatal, cortical, and white matter brain MRI abnormalities in Wilson disease}

Jean-Marc Trocello, France Woimant, Souleiman El Balkhi, et al. Neurology 2013;81;1557

DOI 10.1212/WNL.0b013e3182a95883

\section{This information is current as of October 21, 2013}

\section{Updated Information \& Services}

References

Citations

Subspecialty Collections

Permissions \& Licensing

Reprints including high resolution figures, can be found at: http://n.neurology.org/content/81/17/1557.full

This article cites 2 articles, 0 of which you can access for free at: http://n.neurology.org/content/81/17/1557.full\#ref-list-1

This article has been cited by 3 HighWire-hosted articles: http://n.neurology.org/content/81/17/1557.full\#\#otherarticles

This article, along with others on similar topics, appears in the following collection(s):

All Genetics

http://n.neurology.org/cgi/collection/all_genetics

All Movement Disorders

http://n.neurology.org/cgi/collection/all_movement_disorders

Gait disorders/ataxia

http://n.neurology.org/cgi/collection/gait_disorders_ataxia

Metabolic disease (inherited)

http://n.neurology.org/cgi/collection/metabolic_disease_inherited

MRI

http://n.neurology.org/cgi/collection/mri

Information about reproducing this article in parts (figures,tables) or in its entirety can be found online at:

http://www.neurology.org/about/about_the_journal\#permissions

Information about ordering reprints can be found online:

http://n.neurology.org/subscribers/advertise

Neurology ${ }^{\circledR}$ is the official journal of the American Academy of Neurology. Published continuously since 1951, it is now a weekly with 48 issues per year. Copyright @ 2013 American Academy of Neurology. All rights reserved. Print ISSN: 0028-3878. Online ISSN: 1526-632X.

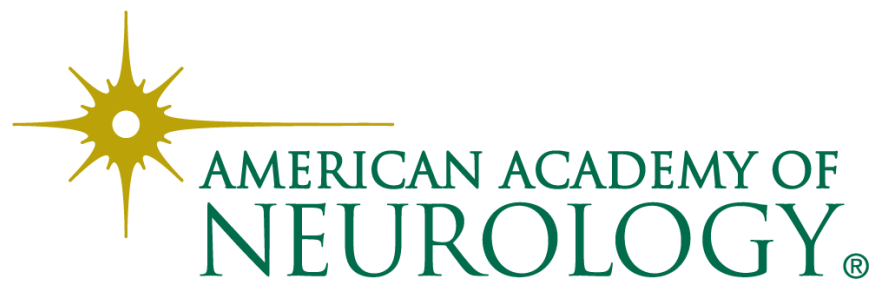

